\title{
Precolonial indigenous leadership: exploring the foundations of leadership culture in Ecuador
}

\author{
Jeffrey L. McClellan \\ Assistant Professor, Management Department, Frostburg State University, MD, USA
}

As there is not much in the academic literature of leadership that explores the historical and foundational roots of leadership culture within specific countries, this paper seeks to address this void. It does so by providing a conceptual model for exploring leadership cultural foundations by examining the motives, goals, and means of influence of leaders through an interdisciplinary review of the literature on social life in precolonial Ecuador. It then applies this model to understanding leadership in the precolonial societies of modern day Ecuador. In doing so, this article summarizes what is known about leadership within these precolonial societies, at the time just prior to the arrival of the Inca and the Spanish, in order to propose a model of precolonial indigenous leadership in Ecuador.

Keywords: Latin American leadership, Ecuador, indigenous leadership

\section{INTRODUCTION}

In his writing on organizational culture, Schein (1992) argued that the founders of an organization have a disproportionate impact on the establishment and perpetuation of cultural patterns within the organization. Thus the initial conditions of leadership within the organization set it on a cultural course that may be altered over time, but that, nonetheless, continues to influence internal leadership norms and practices well beyond the direct involvement of the initial leaders themselves. The same can be said of culture within social entities such as families, communities, and countries, as these possess many of the same characteristics as traditional business organizations (Robbins et al. 2011).

In the literature of international leadership a tremendous amount of research has been conducted to explore the differences in leadership culture and practices across national boundaries (Behrens 2010; Dorfman et al. 1997; Hofstede 1972; 1984; House et al. 2004; 2014; Lenartowiczs and Johnson 2003; Stephens and Greer 1995; Winston and Ryan 2008). At the same time, some work has been dedicated to exploring this phenomenon within specific countries (Abarca 1998; McIntosh 2011; McIntosh and Irving 2010; Muller and Rowell 1997). However, very little has been done to examine the historical and foundational roots of leadership culture within specific countries. As a result, this paper offers a conceptual model for exploring leadership cultural foundations by examining the motives, goals, and means of influence of leaders and applies this model to understanding leadership in the precolonial societies of modern-day Ecuador. To achieve this end, the article overviews the current research regarding the practice of leadership in Ecuador, identifies the 
important elements of leadership cultural analysis, and overviews what is known about precolonial societies in relation to their internal power relations in order to develop and propose a model of precolonial indigenous leadership in Ecuador.

\section{LEADERSHIP IN ECUADOR}

At present, the literature on leadership in Ecuador is extremely limited. The relatively few pieces that have been written on leadership-related topics in Ecuador focus primarily on political leadership (Hurtado 1985; Martz 1983). The GLOBE ${ }^{1}$ (House et al. 2004) research project broadened this emphasis somewhat by exploring business leadership in modern Ecuador. The study examined the culturally implicit ideas of what makes for effective leadership in 62 societies, as well as examining the leadership culture in these societies. Based on the GLOBE results, it appears that in order for a leader to be perceived as outstanding in Ecuador, they must first demonstrate strongly charismatic leadership that is characterized by a visionary, performance-oriented, and inspirational style that demonstrates a willingness to be self-sacrificing. They must also be decisive and demonstrate integrity. Second, they must be status-conscious without being self-protective. Third, they should be more modest in their approach to leadership. Fourth, they should be team-oriented, emphasizing collaboration, integration, and administrative competence that avoids any malevolent actions. Finally, research indicates that there is no major need for them to be more participative (nor should they be less participative) than other leaders. However, based on GLOBE results they will likely need to demonstrate less autonomy and more interdependence.

While the GLOBE study offers a significant and insightful divergent perspective based on an emphasis in the study of business leadership, the sample size for Ecuador is insufficient (49 surveys across three business sectors) to draw any significant and generalizable conclusion regarding leadership in the country (House et al. 2004). As a result, the only knowledge of leadership in Ecuador in the international academic literature comes from historical works and limited survey-based research. However, what has been written generally aligns with the broader research that has been conducted in relation to leadership throughout Latin America. Thus an understanding of leadership in Ecuador may and must largely be based, at present, on the literature for leadership in Latin America.

In general, leadership in Latin America has been characterized by authoritarianism, caudillaje, machismo, populism, and instability (de la Torre 2007; McIntosh and Irving 2010; Osland et al. 2007). The leadership literature for Latin America paints a picture of leadership that is characterized by '(a) simpatia, personal dignity, and classism; (b) particularism; (d) trust; (e) collectivism and in-group/out-group behavior; (f) paternalism; (g) power; (h) humor and joy; and (i) fatalism' (Osland et al. 2007, p. 220). Studies suggest that Latin American leaders tend to demonstrate, or be perceived as demonstrating, more power distance (Hofstede 1980; Triandis et al. 1984) and a greater emphasis on positive relationships (Stephens and Greer 1995) and relationships in general (Lankau and Chung 2009). In addition, Latin American leaders appear to use more 'directive, supportive, contingent reward/ punishment, and charismatic leadership behaviors but not participative' approaches

1. GLOBE stands for Global Leadership and Organizational Behavior Effectiveness. The project explored cultural perceptions of leadership effectiveness in 61 countries throughout the world. 
to leadership (Dorfman et al. 1997). Furthermore, Latin American leaders appear to be less humble in their approach to leadership (McIntosh and Irving 2010). Additional studies and articles validate the findings of these studies and suggest that the patron or caudillo style of leadership predominates in Latin America. At the same time they argue that changes are taking place in the leadership culture of Latin America that result in the rise of more participative leadership styles that appear to align more with models such as servant leadership and transformational leadership (Behrens 2010; Dealy 1992; McIntosh 2011; Romero 2004; 2005).

\section{MODELING LEADERSHIP CULTURE}

If one wishes to understand leadership culture, it is important to understand the nature of leadership. However, leadership is a difficult concept to define (Antonakis et al. 2004). Fortunately, most definitions imply that leadership, as a basic construct, concerns two things: social influence and goal achievement. Thus leadership focuses on how individuals or groups achieve goals through social influence processes. As such, leadership as both a concept and a field of practice is always a product of the culture in which it is situated.

As Schein (1992, p. 10) explained, '[t]he most useful way to think about culture is to view it as the accumulated shared learning of a given group, covering behavioral, emotional, and cognitive elements of the group members' total psychological functioning.' As leadership processes and practices are a natural result of such learning, they are inherently a cultural phenomenon. Consequently, they possess at least three levels of cultural complexity.

According to Schein (ibid.), there are multiple levels of culture, including: artifacts, 'all the phenomena that one sees, hears, and feels' (p. 17); espoused values, which reflect the beliefs about what the artifacts mean and determinations of 'what ought to be as distinct from what is' (p. 19); and finally basic assumptions, beliefs that 'have become so taken for granted that one finds little variation within a cultural unit' (pp. 21-22). While the first two levels aid in the evaluation of culture, Schein argues that the real heart of an organization's culture is its basic assumptions. This is because basic assumptions are the results of success. They are derived from the beliefs about the way that things should be done, upon which the company was built. These beliefs are often those espoused by early leaders, whose actions brought about success, leading those within the organization to accept these beliefs and the resulting behaviors as 'good' business practices and the 'right way' to do business (ibid., p. 21). Once such beliefs are entrenched, they are soon taken for granted. As a result, they become the subconscious drivers of behaviors, policies, and procedures, or, in other words, the culture.

As a cultural phenomenon, leadership occurs at three similar levels. The first, like Schein's artifacts, represents the external manifestations of leadership. This level refers to those things that leaders do to influence others. For the purposes of this paper, this layer will be referred to as the 'means of influence.' The second cultural layer of leadership corresponds with the espoused values layer of culture. In relation to leadership, espoused values represent the motivation and the desired outcomes of one's leadership based on the cultural context in which the leadership takes place. These will be referred to as 'goals as leader.' The final layer of culture, basic assumptions, relates to the underlying motivational drivers of leadership that are embedded within the culture. As it is difficult to examine such subconscious assumptions, one way to do so is by examining the embedded concept of power within the culture. Power is an important element of 
leadership (Heifetz 1994; Pierro and Cicero 2008; Rahim and Buntzman 2001), as it is the foundation upon which social influence is based. What causes a person to be perceived as powerful is based in cultural values and norms that are often subconscious. Thus, one way to understand subconscious leadership values is to explore where the power to lead comes from within the social context. Consequently, the third component in our analysis model of leadership is the sources of power from which leadership is derived. These three cultural elements of leadership - sources of power, goals of the leader, and means of influence - will now be examined in relation to a historical overview of the leadership traditions in precolonial and pre-Inca Ecuador.

\section{PRECOLONIAL LEADERSHIP}

While precolonial Ecuador spans a significant period of time, the focus of this research was on the initial conditions that existed at the time of and just prior to the arrival of the Spanish, and upon which Spanish culture was built. Consequently, the societies that are explored here are largely those that were in existence at the time of the Spanish arrival, though the trends and elements of power-oriented influence certainly predate this period. Precolonial Ecuador, just prior to the conquest, contained numerous different tribal and agricultural societies that were largely politically distinct due to both the geographic and social environment. Among others, Steward and Faron (1959, p. 58) suggested that 'a general dispersal of houses and small settlements prevailed throughout most of the highlands. Common religious devotion brought people from fairly wide areas to worship at central temples or shrines, while needs for defense were met by mountain forest in which the common people found refuge.' In spite of this general structure, some integration was not uncommon and interaction between these social structures was frequent as these societies collaborated, worshiped, traded, and engaged with one another (Grieder 2009; Luciano 2010; Salomon 1986; Stothert 2003). While some of these interactive social groups became quite large, the majority strove for and maintained highly localized political autonomy as part of larger relational structures that were 'not known to have exercised governmental integrating functions over the rest' (Salomon 1986, p. 71). For example, in relation to the Canari of South Central Ecuador, Hirshkind (1995, p. 316) explained, 'before the Inca conquest, there were no Canar people, nation or confederation. Instead, there were local chiefdoms of various sizes sharing a language and certain cultural traditions (ceramics, metal work, religious beliefs, agricultural practices) which distinguished them from neighboring peoples such as the Puruhá to the north, the Palta to the south, and the Shuar to the east.' The existence of such related, even collaborating but not politically unified, societies appears to have predominated in precolonial Ecuador (Bruhns 2003; Luciano 2010; Stemper 1993).

The primary purpose for interaction across these societal structures was economic in nature, though trade may also have had religious connotations and foundations in the formative period (Stothert 2003). In reference to the communities of the north central Sierra, Salomon (1986, p. 72) wrote:

Community members were able neither to enjoy a culturally acceptable standard of living, nor to conduct the transactions that signaled their status as full and active adults, without sharing directly in the production of large exportable surpluses and the importation of diverse exotic goods.

Thus trade was essential to survival and cultural living. In fact, certain groups of the Machalilla may have been so specialized in the working of Spondylus shell, a highly 
valued luxury item in precolonial Ecuador, that they were largely dependent upon trade for some subsistence items such as corn (Martin and Lara 2010). Thus a certain level of interdependency was evident across the various regions of Ecuador.

Regarding leadership structure within these societies, Bray (2008, p. 24) explained, 'in early historic references to the polities of this region, chroniclers often used the term cacicazgo, which approximates the notion of chiefdom, to describe' these societies. The author further described how 'each cacicazgo was composed of numerous villages, or llacta' (ibid., p. 24). According to Salomon (1986, p. 45):

A llajta is a group of persons sharing hereditary rights over certain factors of production (particular lands, the labor of certain people, and specific tools and infrastructures), and recognizing as a political authority a privileged member of their own number.

These privileged members were referred to as a 'native lord,' cacique, or chief. The head of the most powerful llacta was also recognized as what would later be called a caudillo or 'ruler among caciques' (Hamill 1992, p. 10). Both caciques and caudillos practiced leadership through reciprocity where, in exchange for labor and obedience, they collected and distributed resources acquired through communal labor and trade, though they themselves were exempt from subsistence-focused production. Doing so was a central and important element of leadership practice in indigenous communities. Thus economic wealth represented a means of acquiring and maintaining leadership (Grieder 2009; Stemper 1993). This does not mean, however, that only the chief had access to economic resources via trade; indeed, there is evidence that trade was not solely under the direction of those in power (Stemper 1993).

Once trade and agricultural products were acquired, leaders both maintained these as a symbol of power and redistributed these as a means of maintaining loyalty. The chief product for redistribution as a result of labor was corn, or maize. Salomon (1986, p. 81) explained:

The chief's claim to mobilize all village members to produce maize, and to offer all of them the processed maize in return, was a signal of rank only in the sense that this social network was (locally) all-encompassing. The obverse side of the gesture was an emphasis on solidarity, shared identity, and kinlike fellowship. Power over maize was, one might say, power over shared sentiment.

In contrast to the internal redistribution of maize, it appears clothing redistribution was largely 'of exotic manufacture and imported through political channels' (ibid., p. 87). Other exotic goods, such as coca, hatchets, and Spondylus shells, were also likely used in this way.

Another form of redistribution is manifest in the practice of feasting. The hosting of feasts was an important responsibility of leaders and likely served multiple functions. As Stothert (2003, p. 390) explained, feasting and other community rituals 'created the basis for both cooperation and competition, regulated relations with the environment, demonstrated the productive power of families, allowed for the accumulation of prestige, attracted affines and allies, cemented alliances, and reinforced other social relations.'

The redistribution of goods and the giving of personal gifts represents a major element of leadership influence in these societies (Luciano 2010; Salomon 1986; Stemper 1993). However, the nature of these giving processes seems to have different meanings depending upon the group vs individual nature of the gift and what the gift actually was. For example, food seems to have always been redistributed from the leader to the group as a symbol of maintenance of the status quo power relationships. In contrast, 
redistributing treasured items usually occurred from a leader to an individual and 'represented alterations in power structure - the investment of power' (Salomon 1986, p. 95).

Another source of chiefly authority was derived from the chief's role as a religious figure or shaman. The term 'shaman' refers to 'a religious leader, male or female, who (a) acts as an intermediary between the living and the realm of the spirits, (b) is a repository of esoteric knowledge, and (c) may function as a healer, diviner, adjudicator, agent of social control, or political leader' (Stothert 2003, p. 342). Stemper (1993, p. 7) explained that 'a chief's house as a symbol of political and cosmic order seems to indicate that many Northern Andean chiefs performed religious duties.' $\mathrm{He}$ further suggested that ' $[\mathrm{c}]$ hiefs participated in creating monuments that served as "sacred landscapes," where they could reveal their skills in communicating with cosmic powers' (ibid., p. 7). In addition, they provided spiritual 'favors' and gifts to those they led (Luciano 2010; Stothert 2003). These spiritual practices likely contributed to the consolidation of authority and the fostering of communal identity (Stothert 2003).

While all leaders appeared to play a significant role in religious practices, in some societies, particularly those in the Costa and the Selva, leadership authority appears to have been exercised primarily by shamans who exchanged spiritual instruction and privileges for labor and resources (Luciano 2010; Stothert 2003). In some of these societies, shamans may have exercised a form of group leadership as opposed to individual leadership (Luciano 2010). Some communities may have become known for their shamanic practices to such an extent that they 'attracted apprentices and younger shamans desirous of advanced training' thereby becoming 'an economic as well as spiritual asset to their local communities' (Grieder 2009, p. 216). However, not all shamans exercised political leadership. In fact, it is possible that in some communities 'all adult men and women might have been involved in shamanic practice' (Stothert 2003, p. 361). Nonetheless, it is likely that while many shamans may or may not have possessed a formal political leadership role in their community, some who did not likely served as informal leaders and garnered significant leadership influence. Indeed, many 'ethnologists believe that the ideology of those who practice shamanism affects nearly all other aspects of cultural behavior, including ecological regulation, community social reproduction, the creation and exercise of leadership, and the cultural expression of gender' (Stothert 2003, p. 343).

In summary, resources and access to resources, the authority to exact labor along with the use of a 'throne stool,' and the size of one's house were indicators of status, power, and wealth that separated leaders from followers (Salomon 1986). Furthermore, it is likely that these individuals' power was absolute and, in some cases, based on the use of fear and corporal punishment. In many cases they even appear to have held power over the giving and taking of wives and children (Salomon 1986). In summarizing the role of these chiefs, Salomon wrote, 'Quito polities ... lodged stewardship of strategic resources in chiefs, and vested in chiefs the power to dispossess commoners, confiscate their goods, or severely punish them' (ibid., p. 138). As a result, community leaders typically 'concentrated control of communal and craft production in the upper level, but did not politically control household production' (ibid.). Furthermore, 'high ranking nobles were exempt from subsistence production, used conspicuous symbols of rank, and regulated social processes of adjudication and marriage' (ibid.). In summary, Solomon suggested that 'of the fifteen possible leadership functions [attributed to chiefdoms], Quito lords clearly exercised eleven: ambassadorial affairs, war leadership, village labor administration, controlling trade, leading ceremonies, punishing wrongdoers, settling disputes, enforcing moral norms, sponsoring feasts, storing information, and distributing goods' (ibid., p.139). Unfortunately, Solomon did not 
elaborate in detail on these specific functions. Nonetheless, the roles and responsibilities of indigenous caciques were clearly extensive and significant within their local realms, or cacicazgos.

Though most of these social groups did not formally organize politically beyond the local level, there is evidence that some may have developed supra-local political structures (Martin and Lara 2010; Stemper 1993). For the most part, however, these societies were small and based in kinship relations characterized by mutual obligations (Luciano 2010). Furthermore, these cacicazgos, regardless of size, 'were highly stable and successful political entities that produced surplus, had considerable wealth, and participated in a complex web of strategic interactions with neighboring groups' (Bray 2008, p. 25). Many of these societies were integrated into the Inca empire within a half century of the arrival of the Spaniards (Salomon 1986). Though the Inca encountered stiff resistance, the structure of these societies facilitated integration into the Inca polity once they had been conquered.

The level of integration and collaboration among social groups in the Sierra proved to be unique in comparison to the tribal societies of the Amazon and some of the smaller groups of the Costa. In the Amazon in particular, societal groups were much smaller and more clan-like (Steward and Faron 1959). Structured more around religion and hunting/fighting, these tribes were typically led by either shamans and/or warriors who influenced others through spiritual knowledge, kinship relations, and strength (Stothert 2003). Communities in the Costa were also often smaller in size than those in the Sierra and more localized (Steward and Faron 1959). Nonetheless, they tended to be larger and more structured than those of the Amazon, where it was more difficult to generate the resource surpluses necessary to sustain larger and more stratified social structures (ibid.). Thus, the larger and more stratified societies generally demonstrated clearer distinctions between leaders and followers and their roles and privileges. Nonetheless, formal leadership tended to be patriarchal in nature and characterized by reciprocity and redistribution of resources.

\section{MODELING LEADERSHIP IN PRECOLONIAL ECUADOR}

In order to better understand the nature of leadership in precolonial Ecuador, the following model is offered based on analysing the research summarized above and organizing it based on the cultural elements outlined previously (see Table 1).

\subsection{Sources of power}

The issue of power, or 'the mastery that leaders exercise over others' (Earle 1997, p. 3) lies at the very heart of leadership in precolonial Ecuador. Based on the available evidence, most caciques and caudillos appear to have derived their authority from their wealth, religious power, or strength in relation to their kinship network.

Thus, the sources of power identified here are largely consistent with those outlined by Earle (1997): economic, political, and ideological. Economic power, which refers to power derived from the "control over production and exchange of subsistence and wealth' (ibid., p. 7), lay at the very center of political control in communities in precolonial Ecuador. Chiefs clearly exercised control over both subsistence and wealth. Subsistence was overseen through the control that chiefs possessed over labor and its resultant output. Wealth was managed via the chief's capacity to control the means and products of economic exchange. Through these they acquired wealth 
Table 1 Precolonial leadership in Ecuador

\begin{tabular}{lll}
\hline Sources of power & Goals as a leader & Means of influencing others \\
\hline - Kinships and economic & - Increase kinship and & - Demonstrations of strength and \\
networks of influence & economic networks & courage \\
- Paternal heritage and & - Increase wealth and & - Fear and punishment \\
masculinity & surpluses & - Redistribution of resources \\
- Wealth, religion, and & - Exact obedience and & - Management of strategic \\
military strength & labor & relationships \\
- Positions of power & Paternalistic care of & - Acquisition of resources through \\
& followers & trade \\
& & - Sponsoring of feasts \\
& & - Reading ceremonies \\
& & - Resolution of disputes \\
& & Labor administration \\
\hline
\end{tabular}

which they redistributed to those they led. This allowed them to increase their status and authority.

Military power 'derives from coercive compliance' or the capacity to dominate through force (ibid.). Earle argued that the coercive force of military power 'is so elemental that it is some wonder that high civilizations do not rely on it exclusively as the source of political control' (ibid., p. 106). Such military power was clearly evident in the social hierarchy of precolonial Ecuador, especially in some of the more tribal societies of the coast and the Amazon. However, its limitations were also evident. Earle explained that as a source of power, military might is flawed by its own strength. Indeed, it is the very power of the military structures derived from such authority that become the source of its dissolution. As the warrior society grows in strength, the leader's individual prowess ultimately declines and the leader becomes open to overthrow.

As Earle (1997, p. 8) explained, ideology 'derives from routines of compliance. It establishes authority structure and institutionalizes practices of rule.' Ideologically, leadership in precolonial Ecuador was based in kinship relations and religious influence. Kinship relations provided the basis for social influence, whereas religious influence offered additional legitimacy.

For the most part, relationships of influence were grounded in and associated with family connections. As communities were largely made up of people connected via kinship, the chief was typically someone with a strong position within the kinship structure. Furthermore, kinship relations were managed and negotiated to further power and influence. Thus arranged marriages and even sending one's child to be raised by the leader of another llacta were common approaches to building and maintaining strategic and economic ties (Salomon 1986). Furthermore, in many cases, the role of leader was passed through paternal bloodlines. As Salomon (ibid., p. 133) explained, 'the office of chief appears to have passed in the male line, but in a complex fashion allowing optional designation of "nephews" as heirs.' This lack of clarity led to the potential for dissent and usurpation of authority by alternative male heirs, such as the caciques brothers. Thus power and authority roles were open to challenge from fraternal rivals, which is consistent with the challenges Earle (1997) outlines in relation to power based on ideology. 
In addition to kin relations, religious ideology and practice supported chiefly authority and power. As explained previously, most chiefs exercised religious authority and used religion as a foundation for manipulating 'information to make it appear that the ruling elite have both the right and the might to hold onto authority' (ibid., p. 9).

It is worth noting that masculinity was another ideological component of leadership in precolonial Ecuador. Indeed, the ideological, economic, and military authority of leaders was largely bound up in masculine symbolism. Salomon (1986, p. 133) goes on to state that 'there are no local examples of "cacicas" (female chiefs)' in the northern Sierra area of his study. Nonetheless, he indicates that there is evidence of some female chiefs 'in some western lowland chiefdoms' (ibid.). Consequently, the precolonial societies were largely male-dominated.

\subsection{Goals}

The goals of precolonial indigenous leaders focused on increasing their status and wealth so as to generate the surpluses necessary to structure society and engage in redistribution, which allowed for the paternalistic care of followers. In doing so, they maintained an emphasis on the economic, military, and ideological sources of power outlined by Earle (1997).

Ideologically, one of the apparent measures of chiefly prowess was the capacity to expand the size of one's household. According to Salomon (1986, p. 127), 'the ability to collect a large kindred together was the mark of high prestige.' This is not surprising, as increasing the number of dependent persons ensured greater support and loyalty.

Furthermore, from an economic perspective, this provided them with the means to exact obedience and labor from those they led, thus ensuring maintenance of control over subsistence. At the same time, trade and craftwork were essential to both acquisition and maintenance of power as well. Failure to care for the needs of followers through trade and redistribution could open one to challenges from ambitious relatives. Thus it was essential that chiefs managed the economic power they held by controlling the flow of material resources 'to nurture and sustain the alternative power sources' (Earle 1997, p. 7).

Militarily, precolonial Ecuadorian leaders likely exercised military authority as a means of achieving and maintaining the capacity to achieve the other goals of their leadership. Thus coercive power was used to control kinship networks and economic exchange processes, to manage labor, and as an element of paternalistic care for followers, which clearly included the paternal right to punish (Solomon 1986).

In all of this, it is worth noting that power and authority in these societies was likely less one-dimensional and more heterarchical than the traditional concept of the cacique suggests. Indeed, while precolonial Ecuadorian societies were clearly hierarchical, there is evidence that they possessed 'the potential for being ranked in a number of different ways' (Crumley 1995, p. 3). This is evidenced by the potential for threats to power from others who possessed access to strength, kinship, and economic power. Indeed, the very need for strength and its use suggests the reality of diffusion of power, which gave rise to the need for such strength and its expression.

\subsection{Means of influence}

In accomplishing these goals, it appears that leaders used the following means of influence: demonstrations of strength and courage, use of fear and punishment, redistribution of resources, management of strategic relationships, acquisition of resources through 
trade, sponsoring of feasts, leading of religious and community ceremonies, resolution of internal disputes, directing of warfare, and administration of labor. These functions required a high level of leadership competency and the capacity to maintain relationships, administer effectively, and think strategically. Once again, however, these approaches were based on the need to manage the economic, ideological, and military strength of the leader (Earle 1997). Indeed, effective practices at this level of activity allowed leaders to be valued for their problem-solving and management skills which caused them to be 'seen as necessary for a group's survival' (ibid., p. 68).

\section{IMPLICATIONS AND CONCLUSION}

This model provides interesting insights into the roots of leadership culture in Ecuador by providing an understanding of the foundation upon which later leadership cultural values and practices were established. In many cases, colonial Spanish practices were similar to, adapted from, or syncretically blended with the indigenous traditions. For example, like their indigenous predecessors, Spanish leadership was founded upon kinships and economic networks of influence and the redistribution of wealth and power within these networks (Dealy 1992; Kryzanek 1992; McIntosh 2011); paternal heritage, though European customs passed leadership from father to firstborn son; masculinity, Ecuador being considered one of the strongest machismo cultures in Latin America (Foster 2002); positions of power, Spanish society having been characterized by an obsession with the pursuit of titles of nobility and rank (Dealy 1992; Paz and Cepeda 2010); wealth, religion, and military strength (Kryzanek 1992; McIntosh 2011), these three components of Spanish dominance having been central to colonial leadership as economic gain, conversion of the natives, and military conquest were all sources of power for and overarching goals of the conquistadors and those who followed them.

Additional similarities can be found in relation to the goals and means of influence. For example, the notion that with rank comes the right to a leisurely lifestyle was very consistent with the labor-free privileges of caciques (Dealy 1992). In addition, the strong emphasis on kindred relationships based on paternalistic, dependency-promoting leadership (Behrens 2009; 2010; Dealy 1992), the transition from financial- or commodity- to labor-based taxation that occurred in spite of royal censure (Hurtado 2010; Lauderbaugh 2012), authoritarian, personalist leadership practices (Hurtado 2010), and many other commonalities likely both facilitated and strengthened the leadership cultural paradigms that still influence Ecuadorian society today. Consequently, if one wishes to lead effectively in an Ecuadorian context, it is valuable to understand the indigenous roots of the leadership differences that one will encounter in Ecuador. As Lauderbaugh (2012, p. 33) argued, '[a] thorough study of Ecuador's indigenous and colonial history is essential for understanding the nation's current identity and problems.' For example, the current regionalism, the emphasis on social welfare programs as a form of redistribution, the continued strengthening of the autocratic power of the presidency, the personalismo that characterizes the political scene, the machismo and aggressive behavior of political leaders, and many other aspects of today's political and economic context are rooted in precolonial leadership patterns.

In addition to providing some basic cultural awareness, however, there are more immediate and timely reasons for understanding this model. As a self-proclaimed intercultural, multinational' state (National Assembly 2008), Ecuador is unique in the combination of its relative diversity of indigenous groups and the level of indigenous involvement in politics (Lauderbaugh 2012). Additionally, some Ecuadorian indigenous 
groups such as the Otavalo are among the most active and entrepreneurial societies in the world (Meisch 2002). Consequently, those who study and do business in Ecuador are likely to encounter and interact with leaders whose cultural traditions are rooted in the model outlined here. For example, the importance of titles and degrees is still significant in Ecuador today. Racial differences still create social boundaries that are not easily bridged. Paternalistic, reciprocity-based leader-follower relationships are still common, whereby leaders are expected to distribute resources to their followers in exchange for support. Men still dominate the political and economic arena and machismo is still a major factor in Ecuadorian leadership. Also, while these individual traditions and leadership practices will likely deviate from what is presented here in significant ways, understanding their cultural heritage is a valuable strength in managing and maintaining strategic relationships.

Finally, there is value in developing and adding models such as this to the international leadership literature. Unfortunately, most leadership models are grounded in North American and European cultural traditions and, consequently, most international leadership research is similarly based on the leadership philosophies and models of these societies. Furthermore, much of the international leadership literature, especially in Latin America, focuses on cross-national studies at the institutional and organizational levels (Behrens 2010; Dorfman et al. 1997; Hofstede 1972; 1984; House et al. 2004; 2014; Stephens and Greer 1995). This presents limitations in relation to mining the breadth and diversity of leadership practices within national borders. Furthermore, while there are studies that explore leadership within individual countries (Abarca et al. 1998; Irving and McIntosh 2010; McIntosh 2011; McIntosh and Irving 2010; Osland et al. 1998), there are very few that explore leadership outside of the business and political arenas or that examine leadership within cultural subgroups, especially aboriginal subgroups (Julien et al. 2010), within these societies. Consequently, this model provides a unique and important contribution to the literature on leadership in Latin America. 


\section{REFERENCES}

Abarca, N., N. Majluf, and D. Rodriguez (1998), 'Identifying Management in Chile,' International Studies of Management and Organizations, 28(2), 18-37.

Antonakis, J., A.T. Cianciolo, and R.J. Sternberg (2004), 'Leadership: Past, Present, and Future,' in J. Antonakis, A.T. Cianciolo, and R.J. Sternberg (eds), The Nature of Leadership, Thousand Oaks, CA: Sage, pp. 3-15.

Behrens, A. (2009), Culture and Management in the Americas, Stanford, CA: Stanford University Press.

Behrens, A. (2010), 'Charisma, Paternalism, and Business Leadership in Latin America,' Thunderbird International Business Review, 52(1), 21-29.

Bray, T. (2008), 'Ecuador's Pre-Columbian Past,' in C. De La Torre and S. Striffler (eds), The Ecuador Reader: History, Culture, and Politics, Durham, SC: Duke University Press, pp. $15-26$.

Bruhns, K.O. (2003), 'Social and Cultural Development in the Ecuadorian Highlands and Eastern Lowlands during the Formative,' in J.S. Raymond and R.L. Burger (eds), Archaeology of Formative Ecuador, Washington, DC: Dumbarton Oaks Research Library and Collection, pp. $125-174$.

Crumley, C.L. (1995), 'Heterarchy and the Analysis of Complex Societies,' in R.M. Ehrenreich, C.L. Crumley, and J.E. Levy (eds), Heterarchy and the Analysis of Complex Societies, Arlington, VA: The American Anthropological Association, pp. 1-5.

Dealy, G.C. (1992), The Latin Americans: Spirit and Ethos, Boulder, CO: Westview Press.

De la Torre, C. (2007), 'The Resurgence of Radical Populism in Latin America,' Constellations, 14(3), 384-397.

Dorfman, P.W., J.H. Howell, S. Hibino, J.K. Lee, U. Tate, and A. Bautista (1997), 'Leadership in Western and Asian Countries: Commonalities and Differences in Effective Leadership Processes Across Cultures,' Leadership Quarterly, 8(3), 233-274.

Earle, T. (1997), How Chiefs Come to Power: The Political Economy in Prehistory, Stanford, CA: Stanford University Press.

Foster, D. (2002), The Global Etiquette Guide to Mexico and Latin America: Everything You Need to Know for Business and Travel Success, New York: John Wiley.

Grieder, T. (2009), The Art and Archaeology of Challuabamba, Ecuador, 1st edn, Austin: University of Texas Press.

Hamill, H.M. (1992), 'Introduction,' in H.M. Hamill (ed.), Caudillos: Dictators in Spanish America, Norman, OK: University of Oklahoma Press, pp. 3-24.

Heifetz, R.A. (1994), Leadership Without Easy Answers, Cambridge, MA: Belknap Press of Harvard University Press.

Hirschkind, L. (1995), 'History of the Indian Population of Canar,' Colonial Latin American Historical Review, 4(3), 311-342.

Hofstede, G.H. (1972), 'The Colors of Collars,' Columbia Journal of World Business, 7(5), 72-80.

Hofstede, G.H. (1980), 'Motivation, Leadership and Organization: Do American Theories Apply Abroad?' Organizational Dynamics, 9(1), 42-63.

Hofstede, G.H. (1984), 'The Cultural Relativity of the Quality of Life Concept,' Academy of Management Review, 9(3), 389-398.

House, R.J., P.J. Hanges, M. Javidan, P. Dorfman, and V. Gupta (2004), Culture, Leadership, and Organizations: The GLOBE Study of 62 Societies, Thousand Oaks, CA: Sage.

House, R.J., P.W. Dorfman, M. Javidan, P.J. Hanges, and M.F. Sully de Luque (2014), Strategic Leadership Across Cultures: The GLOBE Study of CEO Leadership Behavior and Effectiveness in 24 Countries, Thousand Oaks, CA: Sage.

Hurtado, O. (1985), N.D. Mills Jr. (trans.), Political Power in Ecuador, Boulder, CO: Westview Press.

Hurtado, O. (2010), B. Sipe (trans. and ed.), Portrait of a Nation: Culture and Progress in Ecuador, New York: Madison Books. 
Irving, J. and T. McIntosh (2010), 'Investigating the Value and Hindrance to Servant Leadership in the Latin American Context: Initial Findings from Peruvian Leaders,' Journal of International Business and Cultural Studies, 2(1), 1-16.

Julien, M., B. Wright, and D.M. Zinni (2010), 'Stories from the Circle: Leadership Lessons Learned from Aborginal Leaders,' Leadership Quarterly, 21, 114-126.

Kryzanek, J.S. (1992), Leaders, Leadership, and U. S. Policy in Latin America, Boulder, CO: Westview Press.

Lankau, M.J. and B.G. Chung (2009), 'A Comparison of American and International Prototypes of Successful Managers,' Journal of Leadership Studies, 3(1), 7-18.

Lauderbaugh, G. (2012), The History of Ecuador, Denver, CO: Greenwood.

Lenartowiczs, T. and J. Johnson (2003), 'A Cross-National Assessment of the Latin America Values Managers: Contrasting Hues, Shades of Gray,' Journal of International Business Studies, 34, 266-281.

Luciano, S.O. (2010), Las antiguas sociedades precolombinas del Ecuador: Unrecorrido por la Sala de Arqueologia del Museo Nacional de Ecuador, Quito, Ecuador: Banco Central de Ecuador.

Martin, A.J. and C. Lara (2010), 'La trayectoria del desarrollo social precolombian en el sur de Manabi,' Antropologia: Cuadernos de Investigaciones, 8, 121-147.

Martz, J.D. (1983), 'Populist Leadership and the Party Caudillo: Ecuador and the CFP, 196281,' Studies in Comparative International Development, Fall, 22-49.

McIntosh, T. (2011), Leadership Peruvian Style: How Peruvians Define and Practice Leadership, Bloomington, IN: iUniverse.

McIntosh, T. and J. Irving (2010), 'Evaluating the instrumento de contribucion al liderazgo de siervo (ICLS) for reliability in Latin America,' The Journal of Virtues and Leadership, 1(1), $30-49$.

Meisch, L. (2002), Andean Entrepreneurs : Otavalo Merchants and Musicians in the Global Arena, 1st edn, Austin: University of Texas Press.

Muller, H.J. and M. Rowell (1997), 'Mexican Women Managers: An Emerging Profile,' Human Resource Management, 36(4), 423-435.

National Assembly (2008), Constitution of the Republic of Ecuador, Quito, Ecuador, available at: http://pdba.georgetown.edu/Constitutions/Ecuador/english08.html.

Osland, J.S., M.M. Snyder, and L.H. Hunter (1998), 'A Comparative Study of Managerial Styles Among Female Executives in Nicaragua and Costa Rica,' International Studies of Management and Organizations, 28(2), 54-73.

Osland, J.S., S.D. Franco, and A. Osland (2007), 'Organizational Implications of Latin American Culture: Lessons for the Expatriate Manager,' Economia y Gestia, 7(14), 109-120.

Paz, J.J. and M. Cepeda (2010), 'Caudillos y populismos en el Ecuador,' Polemika, 1(3), 72-81.

Pierro, A. and L. Cicero (2008), 'Motivated Compliance with Bases of Power,' Journal of Applied Social Psychology, 38(7), 1921-1944.

Rahim, M.A. and G.F. Buntzman (2001), 'Supervisory Power Bases, Styles of Handling Conflict with Subordinates, and Subordinate Compliance and Satisfaction,' The Journal of Psychology, 123(2), 195-210.

Robbins, S.P., D.A. DeCenzo, and H. Moon (2011), Fundamentals of Management: Essential Concepts and Applications, Upper Saddle River, NJ: Pearson/Prentice Hall.

Romero, E. (2004), 'Latin American leadership: El patron y el lider moderno,' Cross Cultural Management, 11(3), 25-37.

Romero, E. (2005), 'The Effect of Hispanic Ethnicity on the Leadership Process,' International Journal of Leadership Studies, 1(1), 28-43.

Salomon, F. (1986), Native Lords of Quito in the Age of the Incas: The Political Economy of North Andean Chiefdoms, Cambridge, UK: Cambridge University Press.

Schein, E.H. (1992), Organizational Culture and Leadership, 2nd edn, San Francisco: Jossey Bass.

Stemper, D.M. (1993), J. Camacho (trans.), La persistencia de los cacicazgos prehispánicos en el río Daule, Costa del Ecuador, vol. 7, Pittsburgh, PA: University of Pittsburgh. 
18 Leadership and the Humanities, Vol. 5 No. 1

Stephens, G.K. and C.R. Greer (1995), 'Doing Business in Mexico: Understanding Cultural Differences,' Organizational Dynamics, 24, 39-55.

Steward, J.H. and L.C. Faron (1959), Native Peoples of South America, New York: McGraw-Hill. Stothert, K.E. (2003), 'Expression of Ideology in the Formative Period of Ecuador,' in J.S. Raymond and R.L. Burger (eds), Archaeology of Formative Ecuador, Washington, DC: Dumbarton Oaks Research Library and Collection, pp. 337-421.

Triandis, H.C., J. Lisansky, G. Marin, and H. Betancourt (1984), 'Simpatia as a Cultural Script of Hispanics,' Journal of Personality and Social Psychology, 47(6), 1363-1375.

Winston, B.E. and B. Ryan (2008), 'Servant Leadership as a Human Orientation: Using the GLOBE Study Construct of Human Orientation to Show that Servant Leadership is more Global than Western,' International Journal of Leadership Studies, 3(2), 212-222. 